\title{
ANALISIS PORTOFOLIO SEBAGAI DASAR PENGAMBILAN KEPUTUSAN INVESTASI SAHAM YANG TERDAFTAR DI BEI
}

\author{
Sri Yati \\ STIE Malangkuçeçwara Malang \\ E-mail: sriati@stie-mce.ac.id \\ Telp. 03417581359
}

\begin{abstract}
This study aims to analyze rate of return and risk as the tools to form the portfolio analysis on 15 the most actives stocks listed in Indonesian Stock Exchange. Descriptive analytical method is used to describe the correlation between three variables: stock returns, expected returns of stock market, and beta in order to measure the risk of stocks to help the investors in making the investment decisions. The research materials are 15 the most actives stocks listed in Indonesian Stock Exchange during 2008-2009. The results show that PT. Astra International Tbk. has the highest average expected return of individual stock (Ri) of 308,3355685, while PT. Perusahaan Gas Negara Tbk. has the lowest of $-477,0827847$. The average expected return of stock market $(\mathrm{Rm})$ is 0,00247163 . PT. Astra International Tbk. has the highest systematic risk level of 20229,14205, while the lowest of $-147,5793279$ is PT. Kalbe Farma Tbk. Furthermore, the results also indicate that there are 9 stocks can be combined to form optimal portfolio because they have positive expected returns.
\end{abstract}

\section{Key Words: Analisis Portofolio, Keputusan Investasi Saham}

Keadaan perekonomian Indonesia yang selama beberapa tahun terakhir yang tidak stabil disebabkan oleh beberapa hal yaitu krisis ekonomi, naik turunnya harga minyak dunia, bencana alam besar, dan kondisi makroekonomi yang belum pulih. Hal ini diikuiti oleh terjadinya resesi ekonomi yaitu krisis finansial global yang membuat keadaan ekonomi negara-negara di dunia menjadi tidak stabil. Krisis finansial ini menyebabkan suku bunga tinggi, meningkatnya angka inflasi, dan dampak paling berat yaitu merosotnya perekonomian Indonesia. Melihat kondisi tersebut, pemerintah Indonesia selalu berupaya mendorong tingkat pertumbuhan perekonomian dengan membuat berbagai kebijakan diantaranya kebijakan moneter dengan cara menurunkan suku bunga di Bank Indonesia agar pelaku bisnis bisa leluasa melakukan usahanya.

Upaya yang dilakukan pemerintah ini membutuhkan dana dalam jumlah besar sehingga sangat diperlukan keikutsertaan seluruh lapisan masyarakat dalam bentuk pengerahan dana investasi. Pengerahan dana investasi masyarakat ini dapat melalui lembaga perbankan dan lembaga keuangan non-bank. Salah satu lembaga sumber pendanaan pembangunan di luar sektor perbankan yang memegang peranan penting dalam sistem perekonomian yang bekerja melalui mekanisme pasar adalah melalui pasar modal. Pasar modal merupakan salah satu alternatif investasi dana yang dimiliki masyarakat di samping sektor perbankan dan jenis investasi lainnya. Undang-Undang Pasar Modal No. 8 tahun 1995 tentang Pasar Modal mendefinisikan pasar modal sebagai "Kegiatan yang bersangkutan dengan penawaran umum dan perdagangan efek, perusahaan publik yang 
berkaitan dengan efek yang diterbitkannya, serta lembaga dan profesi yang berkaitan dengan efek". Keberadaan pasar modal membuat para investor dapat mengambil keputusan investasi dengan lebih rasional dan masyarakat memiliki kesempatan yang luas untuk melakukan diversifikasi investasi yang dianggap paling menguntungkan.

Investasi di pasar modal memiliki dua potensi, yaitu deviden yang diharapkan oleh para pemodal dan capital gain. Selain return, kegiatan investasi juga dapat menimbulkan resiko bagi para investor. Semakin besar potensi return yang akan diterima maka semakin besar pula potensi risiko. Jogiyanto (2000) menekankan bahwa risiko investasi ini dibedakan menjadi dua yaitu risiko sistematis (systematic risk) dan risiko non sistematis (unsystematic risk). Sebagai upaya untuk meningkatkan return atas investasi, investor melakukan tindakan memaksimumkan expected return pada berbagai tingkat resiko. Salah satu cara untuk mengurangi tingkat risiko yang ada yaitu dengan melakukan investasi dalam bentuk portofolio. Portofolio didefinisikan sebagai sekumpulan investasi dimana pemodal dapat berinvestasi pada macam-macam saham dengan maksud untuk mengurangi risiko. Sebelum mengambil keputusan berinvestasi investor rasional akan memilih untuk berinvestasi pada portofolio yang paling efisien di antara kumpulan portofolio yang ada. Portofolio yang efisien menurut Jogiyanto (2000) adalah; (a) Portofolio yang memberikan return ekspektasi terbesar dengan risiko tertentu, (b) Portofolio yang memberikan risiko terkecil dengan return ekspektasi tertentu.

Guna mengetahui bagaimana portofolio yang efisien, maka dalam penelitian ini dipilih 15 Saham Teraktif sebagai sampel penelitian berdasarkan pertimbangan bahwa saham-saham ini banyak diminati oleh para investor dan calon investor. Saham-saham tersebut memiliki perkembangan dan fluktuasi harga saham yang tinggi. Meskipun perkembangan harga yang tinggi tidak menjamin akan memberikan capital gain yang besar. Sehingga para investor masih perlu melakukan analisis risiko dan return portofolio sehingga mereka dapat memilih jenis saham yang memberikan return yang diharapkan dengan tingkat risiko tertentu.

Penelitian ini bertujuan untuk menganalisis tingkat return dan tingkat resiko sebagai alat pembentukan portofolio pada 15 saham teraktif yang terdaftar di Bursa Efek Indonesia. Investor dalam melakukan investasi akan memperkirakan berapa tingkat penghasilan yang diharapkan (expected return) atas investasinya untuk suatu periode tertentu di masa datang. Namun, setelah periode investasi berlalu, belum tentu tingkat penghasilan yang terealisasi adalah sama dengan tingkat penghasilan yang diharapkan, tingkat penghasilan yang direalisasikan dapat lebih tinggi atau lebih rendah. Ketidakpastian akan tingkat penghasilan merupakan inti dari investasi, yaitu bahwa pemodal selalu harus mempertimbangkan unsur ketidakpastian yang merupakan risiko investasi. Berdasarkan latar belakang permasalahan yang telah disampaikan maka rumusan permasalahan dalam penelitian ini dapat diuraikan sebagai berikut: "Bagaimana menganalisis portofolio pada 15 saham teraktif sebagai dasar pengambilan keputusan investasi saham di Bursa Efek Indonesia?"

Investasi secara umum diartikan sebagai konsumsi yang ditunda untuk menanamkan kekayaan dengan harapan akan memperoleh tambahan pendapatan di masa depan. Pengertian investasi menurut Halim (2002) adalah penempatan sejumlah dana pada saat ini dengan harapan untuk memperoleh keuntungan di masa mendatang. Investasi juga didefinisikan sebagai penundaan konsumsi sekarang untuk digunakan di dalam produksi yang efisien selama periode waktu tertentu (Jogiyanto, 2000). Investasi didefinisikan jugasebagai kegiatan untuk mengeluarkan sejumlah uang di masa sekarang dengan harapan untuk memperoleh sejumlah pembayaran di masa yang akan datang dengan mempertimbangkan beberapa hal seperti nilai waktu dari uang, tingkat inflasi, dan risiko 
ketidakpastian (Reily dan Brown, 1997). Pihak-pihak yang melakukan kegiatan investasi disebut investor. Investor pada umumnya bisa digolongkan menjadi dua, yaitu investor individual dan investor institusional. Investor individual terdiri dari individuindividu yang melakukan aktivitas investasi. Sedangkan investor institusional biasanya terdiri dari perusahaan-perusahaan asuransi, lembaga penyimpan dana, lembaga dana pensiun, maupun perusahaan investasi.

Pada umumnya tujuan orang melakukan investasi adalah untuk menghasilkan sejumlah uang. Tandelilin (2001) menjelaskan bahwa investasi bertujuan untuk mendapatkan kehidupan yang lebih layak di masa datang, mengurangi tekanan inflasi dan sebagai dorongan untuk menghemat pajak. Pada dasarnya kegiatan investasi dibedakan menjadi dua golongan yaitu Real Investment dan Financial Investment. Real investment adalah kegiatan penanaman modal pada aktiva tetap berupa aset nyata yang dapat dilihat, dipegang, dirasakan, dan jelas bentuknya seperti tanah, mesin, emas, perhiasaan, dan lainlain. Financial investment adalah kegiatan penanaman modal pada aktiva keuangan yang biasanya didokumentasikan dalam bentuk-bentuk yang disahkan secara hukum seperti saham, obligasi, dan lain-lain (Jogiyanto, 2000).

Husnan (1998) menjelaskan bahwa proses investasi menunjukkan bagaimana pemodal seharusnya melakukan investasi dalam sekuritas yaitu menyangkut sekuritas yang akan dipilih, seberapa banyak investasi tersebut, dan kapan investasi tersebut akan dilakukan. Oleh karena itu, untuk mengambil keputusan tersebut maka diperlukan langkah-langkah sebagai berikut: (1)Menentukan kebijakan investasi; (2)Analisis sekuritas; (3) Pembentukan portofolio; (4) Melakukan revisi portofolio; dan (5) Evaluasi kinerja portofolio. Sebagai imbalan atas investasi yang ditanamkan diperoleh tingkat keuntungan. Halim (2002) menjelaskan tingkat keuntungan atau return sebagai imbalan yang diperoleh dari investasi. Return ini dibedakan menjadi dua, pertama return yang telah terjadi (actual return) yang dihitung berdasarkan data historis, dan kedua return yang diharapkan (expected return) akan diperoleh investor di masa mendatang. Komponen return meliputi Capital gain, yaitu merupakan keuntungan (kerugian) bagi investor yang diperoleh dari kelebihan harga jual (harga beli) di atas harga beli (harga jual) yang keduanya terjadi di pasar sekunder, dan Yield yaitu pendapatan atau aliran kas yang diterima investor secara periodik, misalnya berupa dividen/bunga.

Karena return saham merupakan suatu pengharapan atau ekspektasi, maka keputusan yang akan diambil oleh para investor lebih banyak didasarkan pada perkiraan tingkat return yang diharapkan (expected return). Faktor utama yang mempengaruhi besarnya expected return adalah tingkat risikonya (degree of risk). Risiko yaitu besarnya penyimpangan antara tingkat pengembalian yang diharapkan (ER) dengan tingkat pengembalian yang dicapai secara nyata (actual return). Semakin besar penyimpangannya berarti semakin besar tingkat risikonya (Halim, 2002). Apabila dikaitkan dengan preferensi investor terhadap risiko, maka risiko dibedakan menjadi tiga, yaitu: Investor yang suka terhadap risiko (risk seeker), yaitu investor yang apabila dihadapkan pada dua pilihan investasi yang memberikan tingkat pengembalian yang sama dengan risiko yang berbeda, maka ia akan lebih suka mengambil investasi dengan risiko yang lebih besar. Investor yang netral terhadap risiko (risk neutrality) adalah investor yang akan meminta kenaikan tingkat pengembalian yang sama untuk setiap kenaikan risiko. Sedangkan Investor yang tidak suka terhadap risiko (risk averter) adalah Merupakan investor yang apabila dihadapkan pada dua pilihan investasi yang memberikan tingkat pengembalian yang sama dengan risiko yang berbeda, maka ia akan lebih suka mengambil investasi dengan risiko lebih kecil. 
Siamat (1999) menjelaskan bahwa risiko investasi di pasar modal pada prinsipnya semata-mata berkaitan dengan kemungkinan terjadinya fluktuasi harga (price volatility). Halim (2002) menjabarkan bahwa risiko-risiko yang mungkin dapat dihadapi investor tersebut antara lain risiko bisnis (business risk) yaitu risiko yang timbul akibat menurunnya profitabilitas perusahaan emiten, risiko likuiditas (liquidity risk) yaitu risiko yang berkaitan dengan kemampuan saham yang bersangkutan untuk dapat segera diperjual-belikan tanpa mengalami kerugian yang berarti, risiko tingkat bunga (interest rate risk) yaitu risiko yang timbul akibat perubahan tingkat bunga yang berlaku di pasar, risiko pasar (market risk) adalah risiko yang timbul akibat kondisi perekonomian negara yang berubah-ubah dipengaruhi oleh resesi dan kondisi perekonomian lain. Risiko yang lain antara lain risiko daya beli (purchasing power-risk) yaitu risiko yang timbul akibat pengaruh perubahan tingkat inflasi, dimana perubahan ini akan menyebabkan berkurangnya daya beli uang yang diinvestasikan maupun bunga yang diperoleh dari investasi dan risiko mata uang (currency risk) yaitu risiko yang timbul akibat pengaruh perubahan nilai tukar mata uang domestik dengan mata uang negara lain.

Teori-teori yang perlu dipahami dalam berinvestasi akan dijabarkan berikut ini. Portofolio adalah suatu kumpulan investasi atas sejumlah aset. Dalam konteks pasar modal, portofolio dapat diartikan sebagai sekumpulan surat berharga yang didiversifikasi untuk memaksimalkan return dan meminimalkan risiko yang mungkin dihadapi investor. Portofolio diartikan sebagai serangkaian kombinasi beberapa aktiva yang diinvestasi dan dipegang oleh investor, baik perorangan maupun lembaga (Sunariyah, 1998). Teori portofolio mengungkapkan bagaimana melakukan pemilihan portofolio dari sekian banyak aset, untuk memaksimalkan return yang diharapkan pada tingkat risiko tertentu yang bersedia ditanggung investor (Tandelilin, 2001). Teori portofolio bertujuan untuk memilih kombinasi yang optimal dari saham-saham yang dimiliki, dalam arti dapat menghasilkan tingkat keuntungan yang sama tetapi dengan risiko yang lebih rendah, atau dengan risiko yang sama dapat memberikan tingkat keuntungan yang lebih tinggi. Sedangkan return realisasi portofolio (portofolio realized return) merupakan rata-rata tertimbang dari returnreturn realisasi masing-masing sekuritas tunggal di dalam portofolio tersebut. Secara matematis, return realisasi portofolio dapat dihitung sebagai berikut:

$$
\mathrm{Rp}=\sum_{\mathrm{i}=1}^{n}\left(\mathrm{w}_{\mathrm{i}} \cdot \mathrm{R}_{\mathrm{i}}\right)
$$

Notasi:

Rp : return realisasi portofolio

wi : porsi dari sekuritas i terhadap seluruh sekuritas di portofolio

Ri : return realisasi dari sekuritas ke-i

$\mathrm{n}$ : jumlah dari sekuritas tunggal

Sedangkan, return ekspektasi portofolio (portofolio expected return) merupakan rata-rata tertimbang dari return-return ekspektasi masing-masing sekuritas tunggal di dalam portofolio. Secara matematis return ekspektasi portofolio dapat dihitung sebagai berikut:

$$
E(R p)=\sum_{i=1}^{n}\left(w_{i} \cdot E(R i)\right)
$$

Notasi :

$\mathrm{E}(\mathrm{Rp})$ : return ekspektasi dari portofolio 
wi : porsi dari sekuritas i terhadap seluruh sekuritas di portofolio

$\mathrm{E}(\mathrm{Ri})$ : return ekspektasi dari sekuritas ke-i

$\mathrm{n}$ : jumlah dari sekuritas tunggal

Selain mempertimbangkan tingkat keuntungan yang diperoleh pemodal juga akan mempertimbangkan tingkat risiko yang akan diambil. Risiko adalah kemungkinan bahwa hasil yang diharapkan dari investasi berbeda dengan hasil yang dicapai (Sunariyah, 1998). Ada dua jenis risiko yaitu: risiko sistematis yaitu risiko yang tidak dapat dihilangkan, jadi semua jenis saham akan terkena dampaknya sehingga investasi dalam 1 jenis saham atau lebih tidak dapat mengurangi kerugian, dan risiko tidak sistematis yaitu risiko yang hanya berdampak terhadap 1 jenis saham. Risiko ini dapat diminimalisasi dengan melakukan diversifikasi.

Cara mengukur risiko dan return portofolio dijabarkan berikut ini. Tingkat return yang diharapkan dari suatu portofolio tidak lain merupakan rata-rata tertimbang dari return masing-masing saham yang membentuk portofolio tersebut. Hal ini tampak pada rumus:

$$
E(R p)=\sum_{i=1}^{N} X_{i} E\left(R_{i}\right)
$$

Dalam hal ini E (Rp) adalah return yang diharapkan dari portofolio, $\mathrm{Xi}$ adalah proporsi dana yang diinvestasikan pada saham i. Risiko dinyatakan sebagai seberapa jauh return yang diperoleh menyimpang dari yang diharapkan. Namun, adapula yang merumuskan risiko tidak dengan ukuran penyebaran tertentu, tetapi mengukurnya sebagai probabilitas menderita kerugian. Aspek pokok dari teori portofolio adalah konsepsi bahwa kadar risiko yang terkait pada saham yang berbeda dalam portofolio adalah berlainan dengan kadar risiko bila saham tersebut berdiri sendiri. Untuk menaksir deviasi standar dari masingmasing saham yang membentuk portofolio dan koefisien korelasi antar tingkat returnnya (covariance). Deviasi standar portofolio dapat dinyatakan sebagai berikut:

$$
\sigma_{\mathrm{p}}^{2}=\sum_{i=1}^{N} X_{i}{ }^{2} \sigma_{i}^{2}+\sum_{i=1}^{N} \sum_{j=1}^{N} X_{i} X_{j} \sigma_{i j}
$$

Dalam hal ini, $\sigma p$ adalah deviasi standar portofolio, $\sigma_{1}^{2}$ adalah varian return saham i, sedangkan oij adalah covariance antar tingkat return saham (diperoleh dari rumus $\sigma \mathrm{ij}=$ $\rho_{\mathrm{ij}} \sigma_{\mathrm{i}} \sigma_{\mathrm{j}}$ ). Dari rumus tersebut bisa diketahui bahwa risiko portofolio tergantung padarisiko masing-masing saham dalam portofolio, bobot masing-masing saham dalam portofolio, kovarian antar return saham dalam portofolio, dan jumlah jenis saham dalam portofolio (Husnan, 1998). Agar investasi yang dilakukan efisien maka perlu membentuk portofolio yang efisien. Portofolio yang efisien didefinisikan sebagai portofolio yang memberikan return ekspektasi terbesar dengan risiko yang sudah tertentu atau memberikan risiko yang terkecil dengan return ekspektasi yang sudah tertentu (Jogiyanto, 2000). Portofolio yang efisien ini dapat ditentukan dengan memilih tingkat return ekspektasi tertentu dan kemudian meminimumkan risikonya atau menentukan tingkat risiko tertentu dan kemudian memaksimumkan return ekspektasinya. Husnan (1994) menjelaskan bahwa portofolio yang efisien adalah portofolio yang menghasilkan tingkat keuntungan tertentu dengan risiko terendah, atau risiko tertentu dengan tingkat keuntungan tertinggi.

Investor perlu memahami bagaimana pemilihan portofolio yang optimal. Portofolio optimal merupakan portofolio yang dipilih seorang investor dari sekian banyak pilihan yang ada pada kumpulan portofolio efisien (Tandelilin, 2001). Sedangkan Sharpe dan 
Alexander (1995) menekankan bahwa portofolio optimal adalah portofolio yang menawarkan tingkat return tertinggi pada tingkat risiko tertentu, atau yang menawarkan tingkat risiko terendah dari tingkat return tertentu. Portofolio optimal dapat digambarkan dalam suatu garis efisien frontier yang dipakai dalam pemilihan portofolio. Pembentukan efisien frontier didasarkan asumsi-asumsi sebagai berikut: dalam pasar terdapat sejumlah saham yang tersedia sebagai bentuk investasi, Setiap saham memiliki E (Ri) dan $\sigma$ (Ri), sebagian saham dengan $\mathrm{E}(\mathrm{Ri})$ yang sama ternyata memiliki $\sigma(\mathrm{Ri})$ yang berbeda, sebaliknya sebagian yang lain memiliki $\sigma(\mathrm{Ri})$ yang sama ternyata memiliki $\mathrm{E}(\mathrm{Ri})$ yang berbeda, investor cenderung memilih saham dengan $\mathrm{E}(\mathrm{Ri})$ tertinggi atau $\sigma(\mathrm{Ri})$ terendah, investor berusaha meminimalkan risiko investasi melalui proses diversifikasi. Investor lebih menyukai portofolio yang dapat memberikan tingkat return yang lebih besar dengan risiko yang sama. Oleh karena itu, maka mereka akan berusaha mencari efficient frontier dari berbagai kombinasi atau portofolio yang mungkin dibentuk. Kombinasi portofolio yang optimal ini dapat dilihat pada gambar 1 . 


\section{Gambar 1. Kombinasi Portofolio Optimal}

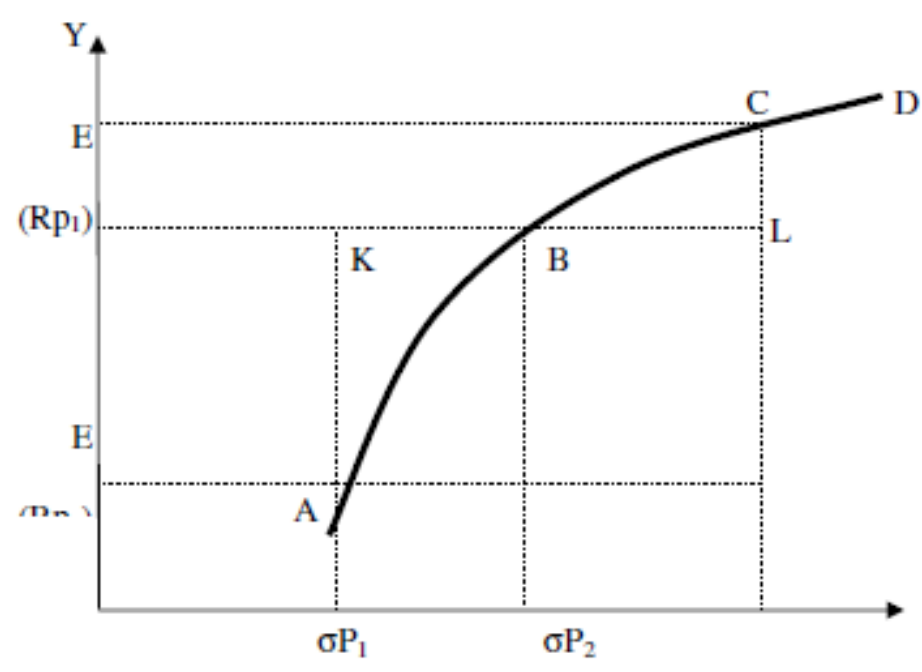

Keterangan:

Sumbu X : Risiko dalam Portofolio, sp

Sumbu Y : Expected Return Portofolio, E (Rp)

Pada gambar ini terlihat bahwa kurva ABCD menunjukkan pasangan portofolio yang optimal. Pasangan di sebelah kiri garis $A B C D$ atau titik $\mathrm{K}$ tidak mungkin tercapai, sebab tidak ada pasangan yang menawarkan expected return sebesar E (Rp2) pada derajat risiko sebesar $\sigma \mathrm{P} 1$. Portofolio yang terdapat di sebelah kanan dari garis efficient frontier, titik L, merupakan portofolio yang tidak optimal. Sebab pada saat yang sama terdapat portofolio lain yang mampu memberikan return yang lebih tinggi pada derajat risiko yang sama. Capital Asset Pricing Model merupakan suatu model yang menghubungkan tingkat return yang diharapkan dari suatu aset berisiko dengan risiko dari aset tersebut pada kondisi pasar yang seimbang. Risiko yang selalu ada dan tidak bisa dihilangkan melalui proses diversifikasi dikenal dengan risiko sistematis. Risiko inilah yang relevan dalam perhitungan risiko. Tolak ukur risiko ini, yang disebut $\beta$, adalah kunci dalam capital asset pricing model. Husnan (1998) menyatakan ukuran dari risiko sistematis dinyatakan dalam bentuk sensitifitas return aset terhadap return pasar dirumuskan sebagai berikut:

$$
\beta \mathrm{i}=\frac{\sigma \mathrm{iM}}{\sigma^{2} \mathrm{M}}
$$

Dimana :

$\beta \mathrm{i}=$ sensitifitas return sekuritas i terhadap return pasar

бiM = covarian return sekuritas i dengan return pasar

$\sigma^{2} \mathrm{M}=$ covarian return pasar

Ada beberapa asumsi yang digunakan pada model CAPM yaitu: semua investor mempunyai distribusi probabilitas tingkat return di masa depan yang identik, karena mereka mempunyai harapan yang hampir sama, semua investor mempunyai satu periode waktu yang sama, semua investor dapat meminjam (borrowing) atau meminjamkan (lending) uang pada tingkat return yang bebas risiko (risk-free rate of return), tidak ada biaya transaksi, tidak ada pajak pendapatan, tidak ada inflasi, semua investor adalah price-taker, pasar dalam keadaan seimbang (equilibrium). 
CAPM merupakan model yang dipergunakan untuk menentukan harga dari suatu aset modal yang dikaitkan dengan risikonya. Model ini mendasarkan pada kondisi ekuilibrium. Dalam keadaan ekuilibrium, tingkat return yang disyaratkan oleh investor oleh suatu saham akan dipengaruhi oleh risiko saham tersebut. Disini risiko ukan lagi diartikan sebagai deviasi standar tingkat return, tetapi diukur dengan Beta $(\beta)$. Penggunaan parameter ini konsisten dengan teori portofolio yang mengatakan bahwa apabila investor melakukan diversifikasi dengan baik, maka pengukur risikonya adalah sumbangan risiko dari tambahan saham ke dalam portofolio. Apabila investor memegang portofolio pasar, maka sumbangan ini tidak lain adalah beta.

\section{METODE}

Jenis penelitian yang digunakan adalah penelitian deskriptif-analitis. Penelitian deskriptif adalah penelitian yang menggambarkan atau melukiskan suatu fenomena dengan jelas, mendeskripsikan sejumlah variabel yang berkenaan dengan masalah yang akan diteliti, dan dalam pengertian yang lebih luas, penelitian deskriptif bukan saja memberikan gambaran, tetapi juga menerangkan hubungan, membuat prediksi, serta mendapatkan makna dan implikasi dari suatu masalah yang akan dipecahkan (Nazir,1998). Sedangkan pada penelitian analitis, analisa ditujukan untuk menguji hipotesa-hipotesa dan mengadakan interpretasi yang lebih dalam tentang hubungan-hubungan.

Penelitian ini bertujuan menjelaskan hubungan tiga variabel yaitu tingkat return saham, expected return pasar saham, dan Beta sebagai pengukur tingkat risiko saham sehingga investor atau calon investor dapat mengambil keputusan yang tepatdalam berinvestasi. Selain itu investor juga dapat membuat prediksi dalam pengambilan keputusan investasi yang akan datang. Setelah itu dengan menggunakan data-data yang ada akan dianalisis hubungan antara tingkat return yang diharapkan dengan risiko yang akan ditanggung dan hasil analisis tersebut akan menginterpretasikan lebih dalam tentang hubungan tiga variabel tersebut dengan pengambilan keputusan investasi. Variable dalam penelitian ini yaitu tingkat return saham, expected return, dan beta. Tingkat return saham yang akan diterima oleh investor dapat dihitung dengan rumus sebagai berikut:

$$
\operatorname{Ri}=\frac{\left(P_{t}-P_{t-1}\right)+D_{t}}{P_{t-1}}
$$

Keterangan :

Ri : return sekuritas ke i

Pt : harga investasi sekarang

Pt-1 : harga investasi periode lalu

Dt : dividen periodic (Jogiyanto, 2000)

Expected return pasar saham E (Rm) dapat dihitung melalui dua cara, yaitu dengan menggunakan indeks harga saham gabungan dan rata-rata return investasi seluruh saham. Dalam penelitian ini peneliti memilih untuk menggunakan perhitungan indeks harga saham gabungan karena hasil yang didapatkan lebih akurat dan lebih halus dibanding menggunakan metode rata-rata. Indeks harga saham gabungan yaitu gabungan seluruh saham yang terdaftar di bursa. Perhitungan return pasar dapat dilakukan dengan rumus sebagai berikut:

$$
\mathrm{R}_{\mathrm{m}}=\frac{\mathrm{IHSG}_{\mathrm{t}}-\mathrm{IHSG}_{\mathrm{t}-1}}{\mathrm{IHSG}_{\mathrm{t}-1}}
$$


Keterangan :

$\mathrm{Rm}$ : Expected return pasar

IHSGt : Indeks Harga Saham Gabungan sekarang

IHSGt-1 : Indeks Harga Saham Gabungan periode lalu (Jogiyanto, 2000)

Sedangkan Beta merupakan pengukur risiko sistematis dari suatu sekuritas atau portofolio relatif terhadap risiko pasar.

$$
\beta i=\frac{\sigma i M}{\sigma^{2} M}
$$

Keterangan :

$\beta \mathrm{i}=$ sensitifitas return sekuritas i terhadap return pasar

$\sigma_{\mathrm{iM}}=$ covarian return sekuritas i dengan return pasar

$\sigma^{2} \mathbf{M}=$ covarian return pasar (Husnan, 1998)

Populasi dalam penelitian ini adalah 15 saham teraktif yang terdaftar dalam Bursa Efek Indonesia periode 2008-2009. Ukuran teraktif disini dilihat dari volume transaksi yang tinggi. Populasi dalam penelitian ini sebagai berikut: (1) Bumi Resources Tbk. (2) Aneka Tambang Tbk. (3) Bank Mandiri Tbk. (4) Astra International Tbk. (5) Tambang Batubara Bukit Asam Tbk. (6) Indofood Sukses Makmur Tbk. (7) Perusahaan Gas Negara (persero) Tbk. (8) Telekomunikasi Indonesia Tbk. (9) Medco Energi International Tbk. (10) Indosat Tbk. (11) Indocement Tunggal Prakarsa Tbk. (12) Kalbe Farma Tbk. (13) Semen Gresik (persero) Tbk. (14) United Tractors Tbk., dan (15) Bank Himpunan Saudara 1906 Tbk. Sampelnya yang digunakan dalam penelitian ini adalah seluruh populasi yaitu 15 saham teraktif yang terdaftar di Bursa Efek Indonesia periode 2008-2009. Sampel yang digunakan berupa 15 saham karena saham-saham ini banyak diminati oleh investor dan calon investor di antara saham-saham lainnya yang terdaftar di Bursa Efek.

Metode pengumpulan data yang sesuai untuk digunakan dalam penelitian ini adalah melalui teknik dokumentasi, yakni pengumpulan data dengan cara mencatat dan meng-copy data sekunder yang tersedia di Bursa Efek Indonesia danselanjutnya direkapitulasi sesuai dengan kebutuhan penelitian. Tujuan dari penggunaan dokumentasi yaitu untuk mengetahui secara jelas mengenai keadaan perusahaan dengan memanfaatkan catatan yang ada. Analisis data yang dilakukan dalam penelitian ini adalah analisis data kuantitatif. Untuk menganalisis dan menginterprestasikan data dengan baik, maka diperlukan data yang akurat dan sistematis agar hasil yang didapat menggambarkan situasi obyek yang diteliti dengan benar. Dalam penelitian saat ini peneliti hanya menggunakan data sekunder. Data sekunder merupakan sumber data penelitian yang diperoleh peneliti secara tidak langsung melalui media perantara (diperoleh dan dicatat oleh pihak lain). Data sekunder umumnya berupa bukti, catatan, atau laporan historis yang telah tersusun dalam arsip (data dokumenter) yang dipublikasikan dan yang tidak dipublikasikan (Indriantoro dan Supomo, 1999).

Adapun tahapan dalam menganalisis data yaitu:

a. Menghitung tingkat return saham i yang akan diterima oleh investor. Dapat dihitung dengan rumus sebagai berikut:

$$
R i=\frac{\left(P_{t}-P_{t-1}\right)+D_{t}}{P_{t-1}}
$$

Keterangan :

$\mathrm{Pt}$ : harga saham pada akhir periode

Pt-1 : harga saham pada awal periode 
Dt : dividen yang diterima selama periode pemilikan saham (Jogiyanto, 2000)

b. Menghitung varian tingkat return saham yang dihitung dengan rumus sebagai berikut:

$$
\sigma_{i}^{2}=\sum_{j=1}^{n} \frac{\left\{R_{j}-E\left(R_{i}\right)\right\}^{2}}{N}
$$

Keterangan :

$\sigma_{\mathrm{i}}^{2}$ : varian saham $\mathrm{i}$

Rij : tingkat return tiap periode

$\mathrm{E}(\mathrm{Ri})$ : tingkat expected return selama periode pemilikan

$\mathrm{N}$ : jumlah periode (Husnan, 1998)

c. Menghitung expected return pasar saham $\mathrm{E}(\mathrm{Rm})$ dengan menggunakan indeks harga saham gabungan. Dapat dihitung dengan rumus sebagai berikut:

Keterangan :

$$
\mathrm{R}_{\mathrm{m}}=\frac{\mathrm{IHSG}_{\mathrm{t}}-\mathrm{IHSG}_{t-1}}{\mathrm{IHSG}_{\mathrm{t}-1}}
$$

$\mathrm{Rm}$ : Expected return pasar

IHSGt : Indeks Harga Saham Gabungan sekarang

IHSGt-1 : Indeks Harga Saham Gabungan periode lalu (Jogiyanto, 2000)

Seperti halnya pengukuran expected return saham individual, untuk mengukur expected return pasar maka hasil perhitungan tingkat return pasar harus dijumlahkan untuk kemudian dibagi dengan jumlah periode observasi.

d. Menghitung Beta $(\beta)$ yang merupakan tolak ukur risiko sistematis dan kunci dari capital asset pricing model.

$$
\beta i=\frac{\sigma \mathrm{iM}}{\sigma^{2} \mathrm{M}}=\frac{\sum(\text { Rit }-\overline{\mathrm{Rit}})(\mathrm{Rmt}-\overline{\mathrm{Rmt}})}{\sum(\mathrm{Rmt}-\overline{\mathrm{Rmt}})^{2}}
$$

Keterangan :

$\beta \mathrm{i}=$ sensitifitas return sekuritas i terhadap return pasar

$\sigma_{\mathrm{iM}}=$ covarian return sekuritas i dengan return pasar

$\sigma^{2} \mathrm{M}=$ covarian return pasar

Rit = return saham individual

$\mathrm{Rmt}=$ return portofolio pasar

Rit $=$ rata-rata Rit

$\mathrm{Rmt}=$ rata-rata Rmt (Jogiyanto, 2000)

\section{HASIL DAN PEMBAHASAN}

\section{Pengukuran Expected Return Saham Individual}

Perhitungan expected return saham individual ini menggunakan data perkembangan saham tiap bulan dan besarnya deviden yang dibagikan oleh 15 saham perusahaan periode 2008-2009. Dari hasil perhitungan tingkat expected return rata-rata bulanan terhadap 15 saham teraktif diketahui bahwa PT. Astra Internasional Tbk. memiliki expected return tertinggi yaitu sebesar 308,3355685. Posisi kedua ditempati oleh PT. Indocement Tunggal Prakarsa Tbk. dengan rata-rata expected return sebesar 229,1678775. Tingginya nilai rata-rata expected return tersebut disebabkan oleh fluktuasi peningkatan harga saham tiap bulan 
periode 2008-2009. Perusahaan yang memiliki expected return paling rendah adalah PT. Perusahaan Gas Negara Tbk. yaitu $-477,0827847$ artinya return rata-rata tersebut menggambarkan kerugian cukup besar. Posisi kedua expected return yang negatif ditempati oleh PT. Indosat Tbk. yaitu dengan nilai -163,540219. Hal ini disebabkan oleh fluktuasi penurunan harga saham selama periode penelitian.

Tabel 2. Hasil Perhitungan Expected Return (Ri) Rata-Rata Bulanan 15 Saham Teraktif

\begin{tabular}{|l|c|}
\hline \multicolumn{1}{|c|}{ Nama Perusahaan } & Expected Return Rata-Rata Bulanan \\
\hline PT. Astra International Tbk. & 308,3355685 \\
\hline PT. Indocement Tunggal Prakasa Tbk. & 229,1678775 \\
\hline PT. Tambang Batubara Bukit Asam Tbk. & 218,75 \\
\hline PT. United Tractors Tbk. & 191,6687905 \\
\hline PT. Semen Gresik Tbk. & 81,25363683 \\
\hline PT. Bank Mandiri Tbk. & 50,00420351 \\
\hline PT. Indofood Sukses Makmur Tbk. & 40,6268237 \\
\hline PT. Bank Himpunan Saudara 1906 Tbk. & 5,505138056 \\
\hline PT. Kalbe Farma Tbk. & 1,667703177 \\
\hline PT. Telekomunikasi Indonesia Tbk. & $-29,16255545$ \\
\hline PT. Aneka Tambang Tbk. & $-94,79166667$ \\
\hline PT. Medco Energi International Tbk. & $-112,49814$ \\
\hline PT. Bumi Resources Tbk. & $-148,9581047$ \\
\hline PT. Indosat Tbk. & $-163,540219$ \\
\hline
\end{tabular}

Keterangan : * Perusahaan yang menghasilkan expected return rata-rata terbesar ** $=$ Perusahaan yang menghasilkan expected return rata-rata terkecil

\section{Pengukuran Expected Return Pasar}

Pengukuran expected return pasar saham $\mathrm{E}(\mathrm{Rm})$ dihitung menggunakan indeks harga saham gabungan karena hasil yang didapatkan lebih akurat dan lebih halus dibandingkan dengan metode rata-rata. Hasil perhitungan expected return pasar dari 15 saham teraktif Bursa Efek Indonesia (BEI) dapat dilihat pada tabel 3. Seperti pengukuran expected return saham individual, untuk mengukur expected return pasar saham maka hasil perhitungan tingkat return pasar dijumlahkan dan kemudian dibagi dengan jumlah periode observasi. Dari hasil perhitungan diketahui bahwa rata-rata expected return pasar saham periode 20082009 yaitu sebesar 0,00247163. Nilai rata-rata return pasar yang positif ini menunjukkan bahwa selama periode pengamatan, saham-saham perusahaan ini mengalami perkembangan dan menunjukkan gejala yang baik.

\section{Pengukuran Risiko Sistematis}

Beta merupakan pengukur risiko sistematis dari suatu sekuritas atau portofolio relatif terhadap risiko pasar (Jogiyanto, 2000). Apabila fluktuasi return-return sekuritas atau 
portofolio secara statistik mengikuti fluktuasi dari return-return pasar, maka Beta dari sekuritas atau portofolio tersebut bernilai 1 . Beta bernilai 1 menunjukkan bahwa risiko sistematik suatu sekuritas atau portofolio sama dengan risiko pasar. Perhitungan risiko sistematis ini dengan menghitung Beta.

Tabel 3. Hasil Perhitungan Expected Return Pasar Saham E (Rm) Periode 2008-2009

\begin{tabular}{|r|r|r|}
\hline IHSG & IHSGt-IHSGt-1 & \multicolumn{1}{c|}{ Rm } \\
\hline 2745,83 & & \\
\hline 2627,25 & $-118,58$ & $-0,043185485$ \\
\hline 2721,94 & 94,69 & 0,036041488 \\
\hline 2447,3 & $-274,64$ & $-0,100898624$ \\
\hline 2304,52 & $-142,78$ & $-0,058341846$ \\
\hline 2444,35 & 139,83 & 0,06067641 \\
\hline 2349,1 & $-95,25$ & $-0,038967415$ \\
\hline 2304,51 & $-44,59$ & $-0,018981738$ \\
\hline 2165,94 & $-138,57$ & $-0,060129919$ \\
\hline 1832,51 & $-333,43$ & $-0,153942399$ \\
\hline 1256,7 & $-575,81$ & $-0,314219295$ \\
\hline 1241,54 & $-15,16$ & $-0,01206334$ \\
\hline 1355,41 & 113,87 & 0,091716739 \\
\hline 1332,67 & $-22,74$ & $-0,016777211$ \\
\hline 1285,48 & $-47,19$ & $-0,035410117$ \\
\hline 1434,07 & 148,59 & 0,115591063 \\
\hline 1722,77 & 288,7 & 0,201315138 \\
\hline 1916,83 & 194,06 & 0,112644172 \\
\hline 2026,78 & 109,95 & 0,057360329 \\
\hline 2323,24 & 296,46 & 0,146271426 \\
\hline 2341,54 & 18,3 & 0,00787693 \\
\hline 2467,59 & 126,05 & 0,053832093 \\
\hline 2367,7 & $-99,89$ & $-0,040480793$ \\
\hline 2415,84 & 48,14 & 0,020331968 \\
\hline 2534,36 & 118,52 & 0,04905954 \\
\hline & & 0,00247163 \\
\hline
\end{tabular}

Hasil perhitungan Beta dari 15 saham teraktif periode 2008-2009 dapat dilihat pada tabel 4. Dari tabel 4 diketahui bahwa sebagian besar saham memiliki Beta positif yang lebih dari 1. Karena memiliki Beta lebih dari 1 maka saham-saham ini tergolong jenis saham ofensif yaitu saham yang aktif mengikuti perubahan pasar sehingga return yang terjadi berfluktuasi mengikuti perubahan pasar. Tabel diatas menunjukkan saham yang memiliki Beta tertinggi yaitu PT. Astra International Tbk. dengan nilai Beta sebesar 20229,14205. Saham-saham yang memiliki Beta positif akan mengalami kenaikan apabila tingkat keuntungan saham-saham yang tercatat di bursa saham meningkat. Sedangkan saham yang memiliki Beta terendah yaitu PT. Kalbe Farma Tbk. dengan nilai Beta sebesar -147,5793279.

Tabel 4. Hasil Perhitungan Rata-Rata Beta Bulanan Periode 2008-2009 


\begin{tabular}{|l|c|}
\hline \multicolumn{1}{|c|}{ Nama Perusahaan } & Beta \\
\hline PT. Astra International Tbk. & 20229,14205 \\
\hline PT. Perusahaan Gas Negara Tbk. & 14742,75347 \\
\hline PT. Bumi Resources Tbk. & 13523,46002 \\
\hline PT. Indocement Tunggal Prakasa Tbk. & 12046,13863 \\
\hline PT. United Tractors Tbk. & 10176,86121 \\
\hline PT. Aneka Tambang Tbk. & 4764,198676 \\
\hline PT. Indofood Sukses Makmur Tbk. & 4618,029277 \\
\hline PT. Semen Gresik Tbk. & 3808,107517 \\
\hline PT. Tambang Batubara Bukit Asam Tbk. & 3639,828115 \\
\hline PT. Indosat Tbk. & 2782,804842 \\
\hline PT. Bank Mandiri Tbk. & 1481,260685 \\
\hline PT. Telekomunikasi Indonesia Tbk. & 1286,444918 \\
\hline PT. Medco Energi International Tbk. & 549,0075674 \\
\hline PT. Bank Himpunan Saudara 1906 Tbk. & 0,506083891 \\
\hline PT. Kalbe Farma Tbk. & $-147,5793279$ \\
\hline
\end{tabular}

\section{Pembentukan Portofolio Optimal}

Berdasarkan analisa dari 15 sampel perusahaan yang diteliti ada beberapa perusahaan yang terpilih untuk menyusun portofolio optimal. Perusahaan yang terpilih ini yaitu perusahaan-perusahaan yang memiliki expected return yang positif. Perusahaan-perusahaan yang merupakan portofolio optimal tersebut dapat dilihat pada tabel 5.

Tabel 5. Saham-Saham yang Terpilih Sebagai Portofolio Optimal

\begin{tabular}{|c|c|c|}
\hline Nama Perusahaan & Expected Retum $\left(\mathrm{R}_{\mathrm{i}}\right)$ & Beta \\
\hline PT. Astra International Tbk. & 308,3355685 & 20229,14205 \\
\hline PT. Indocement Tunggal Prakarsa Tbk. & 229,1678775 & 12046,13863 \\
\hline PT. Tambang Batubara Bukit Asam Tbk. & 218,75 & 3639,828115 \\
\hline PT. United Tractors Tbk. & 191,6687905 & 10176,86121 \\
\hline PT. Semen Gresik Tbk. & 81,25363683 & 3808,107517 \\
\hline PT. Bank Mandiri Tbk. & 50,00420351 & 1481,260685 \\
\hline PT. Indofood Sukses Makmur Tbk. & 40,6268237 & 4618,029277 \\
\hline PT. Bank Himpunan Saudara 1906 Tbk. & 5,505138056 & 0,506083891 \\
\hline PT. Kalbe Farma Tbk. & 1,667703177 & $-147,5793279$ \\
\hline
\end{tabular}

Kesembilan saham di atas dimasukkan sebagai saham yang dapat menjadi portofolio optimal karena saham-saham ini dapat memberikan keuntungan (return) bagi para pemegang sahamnya. Tabel 5 di atas menunjukkan tiga urutan utama saham yang menjadi portofolio optimal yaitu PT. Astra International Tbk. di urutan pertama dengan nilai expected return sebesar 308,3355685 dan Beta senilai 20229,14205. Posisi kedua yaitu PT. Indocement Tunggal Prakarsa Tbk. dengan nilai expected return sebesar 229,1678775 dan Beta senilai 12046,13863. Posisi ketiga yaitu PT. Tambang Batubara Bukit Asam Tbk. dengan nilai expected return sebesar 218,75 dan Beta senilai 3639,828115. Untuk mengetahui alternatif portofolio yang menguntungkan maka dapat disusun beberapa kombinasi portofolio dari sembilan perusahaan tersebut. Sebelum mengkombinasikan portofolio tersebut terlebih dahulu dihitung deviasi standar dari masing-masing jenis saham. Hasil perhitungan deviasi standar tersebut terlihat pada tabel 6.

Tabel 6. Tingkat Keuntungan dan Deviasi Standar Tingkat Keuntungan 


\begin{tabular}{|l|c|c|}
\hline \multicolumn{1}{|c|}{ Nama Perusahaan } & Expected Return $\left(\mathrm{R}_{\mathrm{i}}\right)$ & Deviasi Standar \\
\hline PT. Astra International Tbk. & 308,3355685 & 3108,565705 \\
\hline PT. Indocement Tunggal Prakasa Tbk. & 229,1678775 & 1022,775647 \\
\hline PT. Tambang Batubara Bukit Asam Tbk. & 218,75 & 2008,599041 \\
\hline PT. United Tractors Tbk. & 191,6687905 & 1899,334712 \\
\hline PT. Semen Gresik Tbk. & 81,25363683 & 472,9834501 \\
\hline PT. Bank Mandiri Tbk. & 50,00420351 & 416,2443984 \\
\hline PT. Indofood Sukses Makmur Tbk. & 40,6268237 & 348,9537326 \\
\hline PT. Bank Himpunan Saudara 1906 Tbk. & 5,505138056 & 42,6302786 \\
\hline PT. Kalbe Farma Tbk. & 1,667703177 & 128,8307664 \\
\hline
\end{tabular}

\section{Kombinasi Portofolio Optimal}

Setelah diketahui deviasi standar dari expected return masing-masing saham maka dibentuklah beberapa komposisi dari 9 alternatif portofolio tersebut. hasil perhitungan tingkat keuntungan rata-rata dan deviasi standar dari alternatif-alternatif portofolio tersebut disajikan pada tabel 7. Berdasarkan analisis yang dipilih adalah portofolio 2 karena jika dilihat dan dikaitkan dengan garis efisien frontier serta tingkat bunga bebas risiko, maka yang bersinggungan adalah portofolio 2 .

Analisis dari tabel 7 diketahui bahwa pada portofolio 1 dengan komposisi 0,5 saham PT. Astra International Tbk., 0,3 saham PT. Tambang Batubara Bukit Asam Tbk., dan 0,2 saham PT. Indocement Tunggal Prakarsa Tbk. dengan rata-rata tingkat keuntungan yang diperoleh yaitu 266,6681475 dengan deviasi standar 957,0845506. Pada portofolio 2 dengan komposisi 0,3 saham PT. Astra International Tbk., 0,2 saham PT. Tambang Batubara Bukit Asam Tbk., dan 0,5 saham PT. Indocement Tunggal Prakarsa Tbk. Dengan rata-rata tingkat keuntungan yang diperoleh yaitu 247,7092 dengan deviasi standar 647,7746656. Pada portofolio 3 dengan komposisi 0,2 saham PT. Astra International Tbk., 0,5 saham PT. Tambang Batubara Bukit Asam Tbk., dan 0,3 saham PT. Indocement Tunggal Prakarsa Tbk. dengan rata-rata tingkat keuntungan yang diperoleh yaitu 241,8761 dengan deviasi standar $694,9060831$.

Pada portofolio 4 dengan komposisi 0,5 saham PT. United Tractors Tbk., 0,3 saham PT. Semen Gresik Tbk., dan 0,2 saham PT. Bank Mandiri Tbk. dengan rata-rata tingkat keuntungan yang diperoleh yaitu 130,211327 dengan deviasi standar 549,8641826. Pada portofolio 5 dengan komposisi 0,3 saham PT. United Tractors Tbk., 0,2 saham PT. Semen Gresik Tbk., dan 0,5 saham PT. Bank Mandiri Tbk. dengan rata-rata tingkat keuntungan yang diperoleh yaitu 98,75346627 dengan deviasi standar 349,893343. Pada portofolio 6 dengan komposisi 0,2 saham PT. United Tractors Tbk., 0,5 saham PT. Semen Gresik Tbk., dan 0,3 saham PT. Bank Mandiri Tbk. dengan rata rata tingkat keuntungan yang diperoleh yaitu dengan 93,96183757 dengan deviasi standar 264,6689111. 
Tabel 7. Tingkat Keuntungan Rata-Rata Portofolio dan Deviasi Standar

\begin{tabular}{|c|c|c|c|}
\hline Portofolio & Komposisi & $\begin{array}{c}\text { Rata-Rata Tingkat } \\
\text { Keuntungan }\end{array}$ & $\begin{array}{l}\text { Deviasi } \\
\text { Standar }\end{array}$ \\
\hline 1 & $\begin{array}{l}0,5 \text { PT. Astra International } \\
0,3 \text { PT. Tambang Batubara Bukit Asam } \\
0,2 \text { PT. Indocement Tunggal Prakasa }\end{array}$ & 266,6681475 & 957,0845506 \\
\hline 2 & $\begin{array}{l}0,3 \text { PT. Astra International } \\
0,2 \text { PT. Tambang Batubara Bukit Asam } \\
0,5 \text { PT. Indocement Tunggal Prakasa }\end{array}$ & 247,7092 & 647,7746656 \\
\hline 3 & $\begin{array}{l}0,2 \text { PT. Astra International } \\
0,5 \text { PT. Tambang Batubara Bukit Asam } \\
0,3 \text { PT. Indocement Tunggal Prakasa }\end{array}$ & 241,8761 & 694,9060831 \\
\hline 4 & $\begin{array}{l}0,5 \text { PT. United Tractors } \\
0,3 \text { PT. Semen Gresik } \\
0,2 \text { PT. Bank Mandiri }\end{array}$ & 130,211327 & 549,8641826 \\
\hline 5 & $\begin{array}{l}0,3 \text { PT. United Tractors } \\
\text { 0,2 PT. Semen Gresik } \\
\text { 0,5 PT. Bank Mandiri }\end{array}$ & 98,75346627 & 349,893343 \\
\hline 6 & $\begin{array}{l}0,2 \text { PT. United Tractors } \\
\text { 0,5 PT. Semen Gresik } \\
\text { 0,3 PT. Bank Mandiri } \\
\end{array}$ & 93,96183757 & 264,6689111 \\
\hline 7 & $\begin{array}{l}0,5 \text { PT. Indofood Sukses Makmur } \\
0,3 \text { PT. Bank Himpunan Saudara } 1906 \\
0,2 \text { PT. Kalbe Farma }\end{array}$ & 22,2984939 & 101,0644142 \\
\hline 8 & $\begin{array}{l}\text { 0,3 PT. Indofood Sukses Makmur } \\
0,2 \text { PT. Bank Himpunan Saudara } 1906 \\
\text { 0,5 PT. Kalbe Farma }\end{array}$ & 14,12292631 & 70,32953857 \\
\hline 9 & $\begin{array}{l}\text { 0,2 PT. Indofood Sukses Makmur } \\
\text { 0,5 PT. Bank Himpunan Saudara } 1906 \\
\text { 0,3 PT. Kalbe Farma }\end{array}$ & 11,37824472 & 47,10941959 \\
\hline
\end{tabular}

Pada portofolio 7 dengan komposisi 0,5 saham PT. Indofood Sukses Makmur Tbk., 0,3 saham PT. Bank Himpunan Saudara 1906 Tbk., dan 0,2 saham PT. Kalbe Farma Tbk. dengan rata-rata tingkat keuntungan yang diperoleh yaitu 22,2984939 dengan deviasi standar 101,0644142. Pada portofolio 8 dengan komposisi 0,3 saham PT. Indofood Sukses Makmur Tbk., 0,2 saham PT. Bank Himpunan Saudara 1906 Tbk., dan 0,5 saham PT. Kalbe Farma Tbk. dengan rata-rata tingkat keuntungan yang diperoleh yaitu 14,12292631 dengan deviasi standar 70,32953857. Pada portofolio 9 dengan komposisi 0,2 saham PT. Indofood Sukses Makmur Tbk., 0,5 saham PT. Bank Himpunan Saudara 1906 Tbk., dan 0,3 saham PT. Kalbe Farma Tbk. dengan rata-rata tingkat keuntungan yang diperoleh yaitu dengan 11,37824472 dengan deviasi standar 47,10941959.

Untuk lebih jelasnya kombinasi dari 9 alternatif portofolio disajikan pada grafik sebagai berikut.

Gambar 2 Tingkat Keuntungan dan Risiko Portofolio Saham

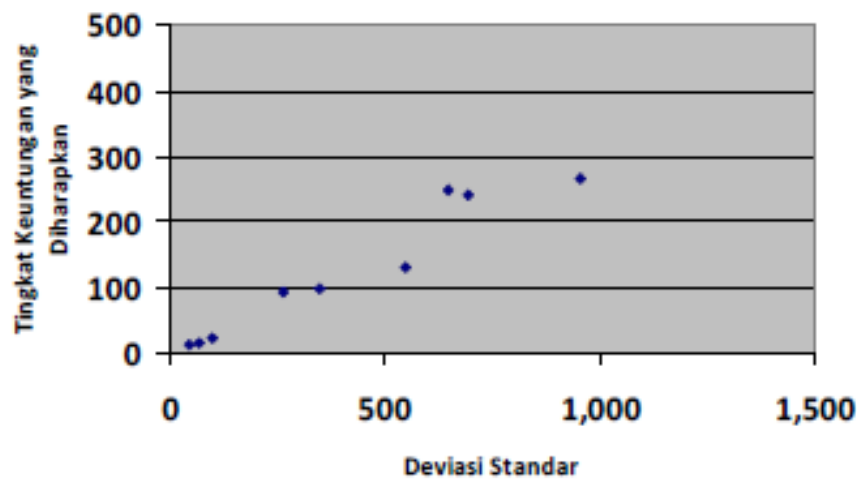




\section{KESIMPULAN DAN SARAN}

\section{Kesimpulan}

Berdasarkan hasil penelitian dari data bulanan 15 saham teraktif maka dapat disimpulkan bahwa penelitian mengenai tingkat return dan risiko sistematis sebagai alat pembentukan portofolio optimal diperlukan dalam investasi di pasar modal. Hal ini dilakukan agar para investor dan calon investor yang ingin mengambil keputusan investasi di Bursa Efek Indonesia dapat mempertimbangkan tingkat pengembalian yang akan didapat dan tingkat risiko yang harus ditanggung. Rata-rata expected return saham individual (Ri) tertinggi adalah PT. Astra International Tbk. yaitu sebesar 308,3355685, sedangkan PT. Perusahaan Gas Negara Tbk. memiliki expected return saham individual (Ri) terendah sebesar $-477,0827847$. Sedangkan rata-rata expected return pasar saham (Rm) adalah 0,00247163 .

Risiko sistematis yang diukur menggunakan Beta saham menunjukkan bahwa Beta sebagian besar saham memiliki nilai positif lebih dari 1. Ketika memiliki Beta lebih dari 1 maka saham-saham ini tergolong jenis saham ofensif yaitu saham yang aktif mengikuti perubahan pasar jadi return yang terjadi berfluktuasi mengikuti perubahan pasar. Tingkat risiko sistematis tertinggi dimiliki oleh PT. Astra International Tbk. sebesar 20229,14205 sedangkan risiko sistematis terendah dimiliki oleh PT. Kalbe Farma Tbk. sebesar 147,5793279. Hasil analisis menunjukkan bahwa ada 9 saham yang dapat dikombinasikan untuk membentuk portofolio optimal. Kesembilan saham ini memiliki expected return positif. Saham-saham ini yaitu PT. Astra International Tbk., PT. Indocement Tunggal Prakarsa Tbk., PT. Tambang Batubara Bukit Asam Tbk., PT. United Tractors Tbk., PT. Semen Gresik Tbk., PT. Bank Mandiri Tbk., PT. Indofood Sukses Makmur Tbk., PT. Bank Himpunan Saudara 1906 Tbk., dan PT. Kalbe Farma Tbk.

\section{Saran}

Berdasarkan hasil penelitian maka Investor yang akan melakukan investasi disarankan tidak berinvestasi pada satu sekuritas saja tetapi melakukan portofolio. Penerapan portofolio saham, maka saham-saham yang ada dapat didiversifikasi untuk memaksimalkan return dan meminimalkan risiko yang mungkin dihadapi investor. Investor dan calon investor harus mampu memilah dan memilih jenis-jenis saham yang akan diambil untuk berinvestasi dengan mempertimbangkan prospek serta risikonya. Sejalan dengan tujuan utama para investor dalam hal mencapai return yang maksimal sehingga investor harus jeli dan berfikir secara rasional. Investor dituntut untuk berfikir logis dalam menyikapi setiap informasi yang diterima. 


\section{DAFTAR RUJUKAN}

Abdurah Rahman. 2005. Analisis Portofolio Optimal Pada Saham LQ45 dengan Pemrograman Non Linear. Jurnal Ekonomi Perusahaan, Vol.12 No.2 Juni 2005, hal.185.

Anoraga, P. dan Nanik Widiyanti. 1995. Pasar Modal Keberadaannya dan Manfaatnya Bagi Pembangunan, Cetakan Pertama, PT. Rineka Cipta, Jakarta.

Arikunto, S. 2006. Prosedur Penelitian Suatu Pendekatan Praktik, Edisi Revisi VI, PT.Rineka Cipta, Jakarta.

Bank Mandiri. 2010. Company Profile. http://www.bankmandiri.co.id/corporate01/about_profile.asp), Diakses 20 Desember 2010

Bank Saudara, 2009. Sejarah Bank Saudara, URL:http://www.banksaudara.com/content/9 , diakses 16 Januari 2010.

BEI. 2010. Bursa Efek Indonesia. www.idx.com.

Halim, A., 2003. Analisis Investasi, Salemba Empat, Jakarta.

Husnan, S. 1998. Dasar-Dasar Teori Portofolio dan Analisis Sekuritas, Edisi Ketiga, UPP AMP YKPN, Yogyakarta.

Indriantoro, N. dan Supomo, B. 1999. Metodologi Penelitian Bisnis untuk Akuntansi $\mathcal{E}$ Manajemen, Edisi Pertama, BPFE, Yogyakarta

Informationmedia. 2009. Indosat-Full Profile, URL:http://persaingantelekomunikasi.wordpress.com/2009/04/23/indosatfullprofile, diakses 26 Desember 2009

Jogiyanto. 2000. Teori Portofolio dan Analisis Investasi, Edisi Kedua, BPFE, Yogyakarta.

Kalbe Farma. (2004), Company in Brief, URL:http://www.kalbe.co.id/about/brief/, diakses 16 Januari 2010

Kalbe Farma. 2004. Introducing, URL:http://www.kalbe.co.id/about/company-profile/, diakses 16 Januari 2010

Katoppo, Aristicles et. al. 1997. Pasar Modal Indonesia Retrospeksi 5 TahunSwastanisasi BEJ, Pustaka Sinar Harapan, Jakarta

Kementerian Negara BUMN. 2007. Tentang Perusahaan, URL:http:/ / portal.bumn.go.id/antam/\#, diakses 09 Februari 2010

Leverage. 2009. Profil Perusahaan, URL:http://leveragekeu230. blogspot.com/2009/02/profil-perusahaan.html, diakses 16 Januari 2010

Nazir,M. 2005. Metodologi Penelitian, Ghalia Indonesia, Bogor.

PT. Aneka Tambang. 2010. Company Profile. http:/ / www.antam.com/index.php?option=com_content\&task=view\&id=32\&Itemid =38, Diakses 20 Desember 2010 
PT. ASTRA International Tbk. 2010. Company in Brief,

URL:http:/ / www.astra.co.id/article.asp, diakses 03 Februari 2010

PT. Bank Mandiri (Persero) Tbk. 2010 Profil Perusahaan,

URL:http://www.bankmandiri.co.id/corporate01/about_profile.asp, diakses 06 Januari 2010

PT. Bukit Asam (Persero) Tbk. 2010. Sejarah Pertambangan Bukit Asam,

URL:http://www.ptba.co.id/indo.php?halaman=Perusahaan.milestone, diakses 10 Januari 2010

PT. Indocement Tunggal Prakarsa Tbk. 2008. Company Overview, URL:http://www.indocement.co.id/new/company.asp, diakses 16 Januari 2010

PT. Perusahaan Gas Negara (Persero) Tbk. 2010 Company in Brief, URL:http://www.pgn.co.id/au_cib.htm, diakses 09 Februari 2010

PT. Telekomunikasi Indonesia Tbk. 2009. Sekilas Telkom, URL:http://www.telkom.co.id/tentang-telkom/sekilas-telkom/ , diakses 03 Februari 2010

PT. United Tractors Tbk, 2009. Business Structure,

URL:http://www.unitedtractors.com/index.php/corporate_overview/business_struc ture, diakses 16 Januari 2010

PT. United Tractors Tbk. 2009. Company Profile, URL:

http://www.unitedtractors.com/index.php/corporate_overview/company_profile , diakses 16 Januari 2010

Samsul, M. 2006. Pasar Modal dan Manajemen Portofolio, Erlangga, Jakarta.

Semen Gresik. 2010. Riwayat Singkat,

URL:http://www.semengresik.com/ina/perusahaanRiwayat.aspx ,diakses 12 Januari 2010

Sharpe, W.F and G.J. Alexander, 1995. Investasi, Jilid 1, Terjemahan Henry Njooliangtik, Agustiono, Prenhallindo, Jakarta.

Siamat, D. 1999. Manajemen Lembaga Keuangan, Edisi Kedua, Lembaga Penerbit Fakultas Ekonomi Universitas Indonesia, Jakarta.

Sumarni, Murti, dan Wahyuni, Salamah, 2005. Metodologi Penelitian Bisnis, ANDI, Yogyakarta.

Sunariyah. 1998. Pengantar Pengetahuan Pasar Modal, UPP AMP YKPN, Yogyakarta.

Tandelilin, E., 2001. Analisis Investasi dan Manajemen Portofolio. Edisi Pertama, BPFE, Yogyakarta.

Wijaya, I.M. 2007. Analisa Makro Ekonomi 2007 dan 2008, URL:http:/ / proilham.blogspot.com/2007/05/analisa-makro-ekonomi-2007-dan-2008_25.html, diakses 09 Februari 2010 
Wikipedia, Medco Energi Internasional,

URL:http://id.wikipedia.org/wiki/Medco_Energi_International , diakses 16 Januari 2010, terakhir dimukhtahirkan 31 Oktober 2009

Yahoo! Inc, 2010. Harga Saham, URL: http:/ finance.yahoo.com/, diakses 18 Oktober 2009 